J urnal Gizi dan Pangan, Maret 2009 4(1): 1 - 7

\title{
GOAL PROGRAMMING: OPTIMALISASI KONSUMSI PANGAN BALITA PADA KELUARGA NELAYAN
}

\author{
(Goal programming: Food consumption optimalization for children under five years \\ in poor under privelaged fishing families) \\ Ikeu Tanziha
}

Departemen Gizi Masyarakat, Fakultas Ekologi Manusia, Institut Pertanian Bogor, Bogor 16680 Telp: 0251-8621258; Fax: 0251-8622276; Email: ikeu_jamilah@yahoo.com

\begin{abstract}
ABST RACT
The objective of the study was to analyze food consumption optimalization for children under five years in poor families. The study design was a cross-sectional study. Research was conducted in Grogol village, in the Gunung Jati sub district, Cirebon. Respondents were all households that have lived in that village for under five years. The data collected include socio economic and demographic data, food expenditure and food intake. An Individual energy adequacy level was calculated by comparing actual intake to RDA (Recommended Dietary Allowances). The goal programming method was applied to analyze food consumption optimalization. The results showed that there are 23 food types for consumption in combination for one week. Per capita food expenditure is Rp 4,194.with Q1 as a lower level and Q3 as an upper level. Goal programming is the solution giving adequate energy and protein levels between $90-110 \%$ and $>77 \%$ for vitamins and minerals.
\end{abstract}

Keywords: goal programming, food consumption optimalization

\section{PENDAHULUAN}

Kemiskinan merupakan masalah serius yang banyak dihadapi oleh negara berkembang. Banyaknya masalah yang dihadapi saat ini baik di bidang sosial maupun kesehatan berakar pada kemiskinan. Lingkaran setan dari kemiskinan apabila tidak segera diputus maka akan selalu menghasilkan generasi selanj utnya yang miskin pula. Kemiskinan pada ujungnya akan menghambat pembangunan.

Daya beli kelompok miskin semakin terpuruk dengan semakin meningkatnya harga kebutuhan sehari-hari. Kemampuan untuk menyediakan pangan yang layak dan sesuai dengan kecukupan gizi yang dianjurkan juga semakin menurun. Hasil penelitian Tanziha (2005) di empat kabupaten di J awa Barat menunjukkan $18.3 \%$ rumah tangga mengalami rawan pangan dan $9.3 \%$ rumah tangga menderita kelaparan. Demikian pula Hardinsyah (2001) menyebutkan bahwa tiga dari 10 anak balita Indonesia mengalami gizi kurang (KEP), tiga dari sepuluh wanita hamil mengalami kurang energi kronik (KEK), enam dari 10 keluarga berpotensi mengalami rawan pangan (food insecurity) karena tidak mampu memenuhi dua per tiga dari kebutuhan pangannya.

Agar permasalahan gizi pada balita tidak terus berlanjut khususnya bagi keluarga miskin, maka perlu dilakukan berbagai upaya un- tuk mengatasi masalah gizi yang terjadi, diantaranya adalah dengan menyusun suatu perencanaan konsumsi pangan yang tepat yang memenuhi kebutuhan gizi, sesuai dengan kebiasaan konsumsinya dan serta terjangkau daya beli keluarga miskin.

Tujuan penelitian ini adalah (1) menganalisis besarnya biaya yang digunakan untuk konsumsi balita setiap harinya pada keluarga nelayan miskin, (2) menganalisis kebiasaan konsumsi pangan balita serta batas bawah dan batas berat pangan yang dikonsumsi, dan (3) menganalisis perencanaan menu bagi balita sebagai upaya perbaikan gizi.

\section{METODE PENELITIAN}

Desain, Tempat, dan Waktu Penelitian

Desain penelitian yang digunakan adalah cross-sectional. Lokasi penelitian adalah di Desa Grogol Kecamatan Gunung Jati Kabupaten Cirebon. Lokasi penelitian diambil secara purposif berdasarkan tingkat kemiskinan tinggi > 20\% Penelitian dilaksanakan pada bulan Februari sampai J uli 2007.

\section{Jumlah dan Cara Penarikan Contoh}

Contoh dalam penelitian ini adalah keluarga nelayan yang tinggal di Desa Grogol, Kecamatan Cirebon Utara, Kabupaten Cirebon, Provinsi Jawa Barat. Pengambilan populasi 
contoh dilakukan secara purposive dengan kriteria keluarga yang memiliki tingkat kesejahteraan terkategori miskin menurut BKKBN (PraSejahtera dan Keluarga Sejahtera 1) ada sebanyak 187 keluarga. Keluarga yang mempunyai balita umur 4-5 tahun hanya ada 15 keluarga dan seluruhnya diambil sebagai contoh.

\section{Jenis dan Cara Pengumpulan Data}

Data yang digunakan dalam penelitian ini berupa data primer dan sekunder. Data primer meliputi: Karakteristik keluarga (besar keluarga, lama pendidikan terakhir, jenis pekerjaan, pengeluaran, umur, berat badan, dan jenis kelamin) yang diambil melalui wawancara dan data pola konsumsi pangan (jumlah, jenis, dan frekuensi konsumsi) yang diambil melalui recall $2 \times 24$ jam dan semi kuantiatatif FFQ. Data sekunder diambil kecamatan dalam angka dan dari potensi desa setempat.

\section{Analisis Pengelolaan Perikanan di Wilayah Pesisir}

Pengolahan dan analisis data dilakukan dengan menggunakan Microsoft Excel 2003, SPSS for Window versi 13.0 dan SAS (Statistical Analysis System) for Window versi 9.1. Peng- kategorian variabel dilakukan dengan cara sebagai berikut:

Data konsumsi pangan individu yang diolah adalah konsumsi energi, protein, vitamin A, B, C, dan kalsium dengan menggunakan Daftar Komposisi Bahan Makanan (DKBM). Selanjutnya dihitung tingkat kecukupan dari masingmasing zat gizi tersebut, melalui perbandingan antara konsumsi aktual dengan kecukupan zat gizi yang dianjurkan (WNPG, 2004).

Biaya konsumsi pangan didasarkan atas pertimbangan besarnya pengeluaran pangan per kapita per hari. Kemudian dalam proses pembuatan rancangan menu digunakan prinsip optimalisasi zat gizi dan minimalisasi biaya konsumsi pangan dengan menggunakan biaya konsumsi pangan sebagai fungsi tujuan dalam goal programming (Siswanto, 1991; Akmal, 2003).

\section{Rancangan Menu Makanan Keluarga menggu- nakan Goal Programming}

Rancangan menu makanan didasarkan atas karakteristik, pola konsumsi pangan, AKG, dan biaya konsumsi pangan. Rancangan menu dibangun dengan menggunakan goal programming sebagai berikut:

Fungsi tujuan

Minimumkan: $\mathrm{z}=d b_{1}{ }^{*}+d b_{2}{ }^{*}+d b_{3}{ }^{*}+d b_{4}^{*}+d b_{5}^{*}+d b_{6}^{*}+d b_{7}{ }^{*}+d a_{1}{ }^{*}+d a_{2}{ }^{*}+d a_{3}{ }^{*}+d a_{4}{ }^{*}+d a_{5}{ }^{*}+d a_{6}{ }^{*}+d a_{7}^{*}$ Kendala-kendala (sasaran dan pembatas)

1. Berdasarkan tingkat konsumsi zat gizi

\begin{tabular}{|c|c|}
\hline Energi & 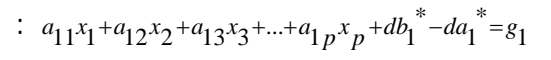 \\
\hline Protein & $: a_{21^{x}} 1_{1}+a_{22} x_{2}+a_{23^{x}}{ }_{3}+\ldots+a_{2 p^{x}} p^{+d b_{2}}{ }^{*}-d a_{2}{ }^{*}$ \\
\hline Vitamin A & $: a_{31} x_{1}+a_{32} x_{2}+a_{33^{x}}{ }_{3}+\ldots+a_{3 p^{x}} p+d b_{3}^{*}$ \\
\hline Vitamin C & 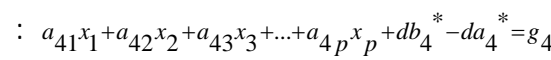 \\
\hline Kalsium & $: a_{51} x_{1}+a_{52} x_{2}+a_{53} x_{3}+\ldots+a_{5 p^{x}} p^{+d l}$ \\
\hline Zat besi & 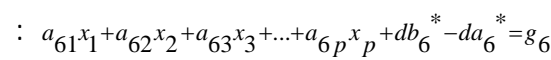 \\
\hline
\end{tabular}

2. Berdasarkan kemampuan biaya untuk pangan dan harga masing-masing pangan

$$
a_{1} x_{1}+a_{2} x_{2}+a_{3} x_{3}+\ldots+a_{p} x+d b_{7}{ }^{*}-d a_{7}{ }^{*}=y
$$

3. Batasan kebiasaan kuantitas pangan yang dikonsumsi berdasarkan $\mathrm{Q}_{1}$ (kuartil bawah) dan $\mathrm{Q}_{3}$ (kuartil atas): $c b_{11} \leq x_{1} \leq b_{21}, b_{12} \leq x_{2} \leq b_{22}, b_{13} \leq x_{3} \leq b_{23}, \ldots, b_{1 p} \leq x_{p} \leq b_{2 p}$

Selanjutnya agar sebanding, model diatas diubah sebagai berikut :

Fungsi tujuan

Minimumkan: $z=d b_{1}+d b_{2}+d b_{3}+d b_{4}+d b_{5}+d b_{6}+d b_{7}+d a_{1}+d a_{2}+d a_{3}+d a_{4}+d a_{5}+d a_{6}+d a_{7}$ 
Kendala-kendala (sasaran dan pembatas)

1. Berdasarkan tingkat konsumsi zat gizi

$$
\begin{aligned}
& \text { Energi } \quad: \frac{a_{11^{x}} 1_{1}+a_{12} x_{2}+a_{13^{x}} 3+\ldots+a_{1 p^{x}} p}{g_{1}}+d b_{1}-d a_{1}=1 \\
& \text { Vitamin A : } \frac{a_{31^{x_{1}}+a_{32^{x}} x_{2}+a_{33^{x}}+\ldots+a_{3 p^{x}} p}}{g_{3}}+d b_{3}-d a_{3}=1 \\
& \text { Kalsium }: \frac{a_{51} x_{1}+a_{52} x_{2}+a_{53} x_{3}+\ldots+a_{5} p^{x} p}{g_{5}}+d b_{5}-d a_{5}=1 \\
& \text { Protein } \quad: \frac{a_{21} x_{1}+a_{22} x_{2}+a_{23^{x}}+\ldots+a_{2 p^{x}} p}{g_{2}}+d b_{2}-d a_{2}=1
\end{aligned}
$$

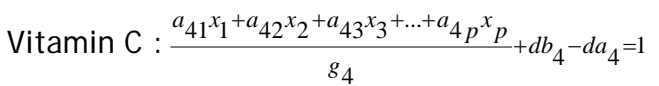

$$
\begin{aligned}
& \text { Zat besi }: \frac{a_{61} x_{1}+a_{62}{ }^{x}{ }_{2}+a_{63} x_{3}+\ldots+a_{6 p^{x}} p}{g_{6}}+d b_{6}-d a_{6}=1
\end{aligned}
$$

2. Berdasarkan kemampuan biaya untuk pangan dan harga masing-masing pangan

$$
\frac{a_{1} x_{1}+a_{2} x_{2}+a_{3} x_{3}+\ldots+a_{p} x_{p}}{y}+d b_{7}-d a_{7}=1
$$

3. Batasan kebiasaan kuantitas pangan yang dikonsumsi berdasarkan $\mathrm{Q}_{1}$ (kuartil bawah) dan $\mathrm{Q}_{3}$ (kuartil atas) : $b_{11} \leq x_{1} \leq b_{21}, b_{12} \leq x_{2} \leq b_{22}, b_{13} \leq x_{3} \leq b_{23}, \ldots, b_{1 p} \leq x_{p} \leq b_{2 p}$

Keterangan :

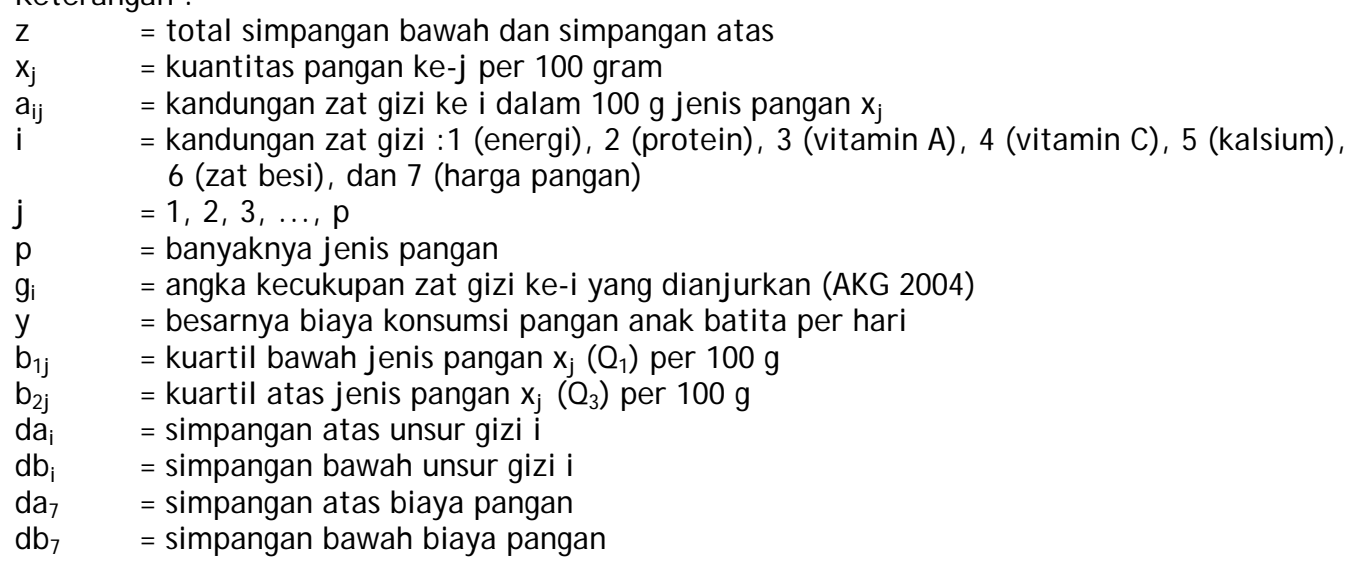

\section{HASIL DAN PEMBAHASAN}

\section{Karakteristik Keluarga dan Balita}

J umlah anggota keluarga berkisar antara 2 sampai 12 orang dengan rataan $5.49 \pm 2.12$ orang. Proporsi terbesar (38.46\%) contoh termasuk dalam keluarga sedang (5-6 anggota keluarga), selebihnya $36.92 \%$ termasuk dalam keluarga kecil ( $\leq 4)$ dan $24.62 \%$ contoh termasuk dalam keluarga besar ( $\geq 7$ ).

Usia kepala keluarga contoh berkisar antara 25-70 tahun dengan rataan $40.23 \pm 11.50$ tahun, sedangkan usia ibu berkisar antara 2066 tahun dengan rataan $36.23 \pm 9.87$ tahun. Baik kepala keluarga maupun ibu sebagian besar yaitu masing-masing $64.62 \%$ dan $69.23 \%$ masuk dalam kelompok dewasa awal (18-40 tahun).

Lama pendidikan kepala keluarga berkisar antara 0-15 tahun dengan rataan $2.86 \pm$ 3.18 tahun, sedangkan ibu berkisar antara 0-12 tahun dengan rataan $3.06 \pm$ 3.32. Sebagian besar kepala keluarga (72.31\%) dan (69.23\%) ibu hanya berpendidikan SD.
Umur balita yang dimaksud berumur 4-5 tahun. Sebesar $33 \%$ perempuan, $82 \%$ status gizi normal dan hanya $18 \%$ status gizi kurang.

\section{Biaya Konsumsi Pangan Keluarga dan Balita}

Salah satu strategi yang harus digunakan dalam membuat suatu perencanaan konsumsi pangan diantaranya melakukan analisis biaya konsumsi pangan. Pengeluaran untuk pangan di Indonesia menurut BPS (1990) masih merupakan bagian terbesar dari total pengeluaran rumah tangga, yaitu lebih dari $50 \%$ Mengingat sasaran penelitian ini adalah keluarga miskin dan anak balita dari keluarga miskin, biaya konsumsi pangan tentu menjadi suatu hal yang sangat penting karena akan mempengaruhi daya beli keluarga tersebut terhadap pangan yang akan dikonsumsi. Daya beli keluarga dipengaruhi oleh besarnya pendapatan yang diperoleh (Tanziha, 2008).

Tabel 1 dan 2 menunjukkan rata-rata pengeluaran pangan dan pengeluaran non pangan keluarga dan untuk balita. Rata-rata pendapatan keluarga sebesar Rp 754 006/bulan atau sebesar Rp 25 133/ hari. J umlah tersebut menunjukkan bahwa umumnya keluarga nela- 
yan tergolong dalam kategori miskin karena bila dibuat per kapita maka rata-rata pendapatan, yaitu sebesar Rp 155415.2 masih di bawah garis kemiskinan. Seperti yang telah dikemukakan diatas bahwa besarnya pendapatan dapat mempengaruhi daya beli seseorang atau keluarga terhadap pangan yang akan dikonsumsi. Oleh sebab itu dalam analisis biaya pangan juga mempertimbangkan besarnya pengeluaran khususnya pengeluaran pangan.

Berdasarkan Tabel 1, rata-rata pengeluaran pangan keluarga lebih besar bila dibandingkan dengan rata-rata pengeluaran non pangannya. Dengan demikian, sebagian besar pengeluaran keluarga dialokasikan untuk memenuhi kebutuhan pangan. Adapun rasio pengeluaran pangan keluarga terhadap pendapatannya adalah sebesar $68.10 \%$ Hal ini sesuai dengan yang ditunjukkan oleh data Susenas (1996 \& 1998) bahwa pengeluaran untuk pangan bagi rumah tangga miskin berkisar antara 60-80\% dari pendapatan (Soekirman, 2000). Rata-rata pengeluaran pangan keluarga miskin adalah sebesar Rp 513 499/ bulan atau sebesar Rp 17 116/hari, dengan minimum pengeluaran sebesar Rp 5311 dan maksimum pengeluaran sebesar Rp 34880.

Tabel 2 menunjukkan rata-rata pengeluaran pangan dan pengeluaran non pangan khusus balita. Rata-rata pengeluaran total untuk balita adalah sebesar Rp 173336 per kapita/ bulan atau sebesar Rp 5978 per kapita/hari. Rata-rata pengeluaran pangan anak balita adalah sebesar Rp 125820 per kapita/bulan atau sebesar Rp 4194 per kapita/hari dengan pengeluaran minimum sebesar Rp 1410 dan maksimum pengeluaran sebesar Rp 6591. J umlah inilah yang selanj utnya akan digunakan sebagai dasar alokasi biaya konsumsi pangan dalam penyusunan menu makanan anak balita. Biaya yang dihasilkan dari rancangan menu makanan diharapkan masih di bawah Rp 4194 per hari sehingga sesuai dengan daya beli keluarga terhadap konsumsi pangannya. Alokasi pengeluaran pangan digunakan untuk pembelian beberapa jenis kelompok pangan seperti pangan pokok (beras), pangan nabati (kacang-kacangan, tahu, dan tempe), pangan hewani (ikan, daging, dan telur), sayur, buah, dan kelompok pangan lainnya (bumbu, minyak goreng, jajanan, dan sebagainya).

\section{Kebiasaan Konsumsi Pangan}

J enis pangan yang dikonsumsi balita berjumlah 67 jenis pangan, namun disini hanya dicantumkan 23 jenis pangan yang reltif lebih banyak balita mengkonsumsinya (Tabel 3). Dari Tabel 3 terlihat ada 5 jenis pangan sebagai sumber karbohidrat, 4 jenis pangan sebagai sumber protein hewani, 3 jenis pangan (tempe, tahu, dan kacang hijau) sebagai sumber protein nabati, dan 10 jenis pangan sebagai sumber vitamin, dan mineral.

Sebagai sumber karbohidrat beras, roti, dan biskuit merupakan jenis pangan yang dikonsumsi setiap hari oleh sebagian balita (100\% 26.67\% dan 53.33\%). Sumber protein hewani, telur ayam merupakan jenis pangan yang dikonsumsi setiap hari oleh sebagian besar balita (80\%), menyusul ikan segar (26.67\%), dan susu kental manis (26.67\%). Sebagai sumber protein nabati, tempe merupakan jenis pangan yang dikonsumsi setiap hari oleh

Tabel 1. Rata-rata Pengeluaran Keluarga untuk Pangan dan Nonpangan

\begin{tabular}{|c|c|c|c|c|c|c|c|}
\hline \multirow{3}{*}{ Keterangan } & \multicolumn{6}{|c|}{ Pengeluaran keluarga (Rp/...) } & \multirow{3}{*}{$\begin{array}{c}\text { Jumlah } \\
\text { anggota } \\
\text { keluarga } \\
\text { (orang) }\end{array}$} \\
\hline & \multicolumn{2}{|c|}{ Pangan } & \multicolumn{2}{|c|}{ Nonpangan } & \multicolumn{2}{|c|}{ Total } & \\
\hline & Bulan & Hari & Bulan & Hari & Bulan & Hari & \\
\hline Rata-rata & 513499 & 17116 & 240507 & 16363 & 754006 & 25134 & 6 \\
\hline Minimum & 159346 & 5311 & 95154 & 1981 & 254500 & 8483 & 2 \\
\hline Maksimum & 1046427 & 34880 & 1124406 & 58337 & 2,170833 & 72361 & 12 \\
\hline Standar deviasi & 202705 & 6756 & 365123 & 12170 & 911296 & 30376 & 2 \\
\hline *) Rasio \% & \multicolumn{2}{|c|}{68.10} & \multicolumn{2}{|c|}{31.90} & & & \\
\hline
\end{tabular}

Tabel 2. Rata-rata Pengeluaran untuk Konsumsi Balita untuk Rancangan Menu Balita

\begin{tabular}{lrrrrrr}
\hline \multirow{2}{*}{ Keterangan } & \multicolumn{6}{c}{ Pengeluaran (Rp/kap/...) } \\
\cline { 2 - 7 } & \multicolumn{2}{c}{ Pangan } & \multicolumn{2}{c}{ Nonpangan } & \multicolumn{2}{c}{ Total } \\
\cline { 2 - 7 } & \multicolumn{1}{c}{ Bulan } & Hari & \multicolumn{1}{c}{ Bulan } & Hari & \multicolumn{1}{c}{ Bulan } & Hari \\
\hline Rata-rata & 125820 & $\mathbf{4 1 9 4}$ & 53520 & 1784 & 173336 & 5978 \\
Minimum & 42285 & 1410 & 19685 & 656 & 61970 & 2066 \\
Maksimum & 197725 & 6591 & 112350 & 3745 & 310075 & 10336 \\
Standar deviasi & 50013 & 1667 & 37790 & 2259 & 71422 & 2047 \\
\hline
\end{tabular}


Tabel 3. Frekuensi Konsumsi Pangan Balita berdasarkan J enis Pangan

\begin{tabular}{|c|c|c|c|c|c|c|c|c|c|c|}
\hline \multirow{4}{*}{ Sumber Zat Gizi } & \multicolumn{10}{|c|}{ Frekuensi makan } \\
\hline & \multirow{2}{*}{\multicolumn{2}{|c|}{$\begin{array}{c}\text { Setiap hari } \\
(\geq 7) / \mathrm{Mg}\end{array}$}} & \multirow{2}{*}{\multicolumn{2}{|c|}{$\frac{\text { Sering }}{(4-6) / \mathrm{Mg}}$}} & \multirow{2}{*}{\multicolumn{2}{|c|}{$\begin{array}{c}\text { Jarang } \\
(1-3) / \mathrm{Mg}\end{array}$}} & \multirow{2}{*}{\multicolumn{2}{|c|}{$\begin{array}{c}\text { Jarang sekali } \\
(1-3) / B \ln \end{array}$}} & \multirow{2}{*}{\multicolumn{2}{|c|}{$\begin{array}{c}\text { Tidak pernah } \\
\text { 0/Bln }\end{array}$}} \\
\hline & & & & & & & & & & \\
\hline & $\mathrm{n}$ & $\%$ & $\mathrm{n}$ & $\%$ & $\mathbf{n}$ & $\%$ & $\mathrm{n}$ & $\%$ & $\mathrm{n}$ & $\%$ \\
\hline \multicolumn{11}{|l|}{ Sumber Karbohidrat } \\
\hline Beras & 15 & 100.00 & 0 & 0.00 & 0 & 0.00 & 0 & 0.00 & 0 & 0.00 \\
\hline Mie & 0 & 0 & 5 & 33.33 & 10 & 66.67 & 0 & 0.00 & 0 & 0.00 \\
\hline Roti & 4 & 26.67 & 4 & 26.67 & 7 & 46.67 & 0 & 0.00 & 0 & 0.00 \\
\hline Biskuit & 8 & 53.33 & 3 & 20.00 & 4 & 26.67 & 0 & 0.00 & 0 & 0.00 \\
\hline $\begin{array}{l}\text { Ubi Kayu } \\
\text { Sumber Protein Hewani }\end{array}$ & 0 & 0.00 & 1 & 6.67 & 6 & 40.00 & 7 & 46.67 & 1 & 6.67 \\
\hline Daging Ayam & 0 & 0.00 & 0 & 0.00 & 3 & 20.00 & 12 & 80.00 & 0 & 0.00 \\
\hline Telur ayam & 12 & 80.00 & 3 & 20.00 & 0 & 0.00 & 0 & 0.00 & 0 & 0.00 \\
\hline Ikan Segar & 4 & 26.67 & 5 & 33.33 & 6 & 40.00 & 0 & 0.00 & 0 & 0.00 \\
\hline $\begin{array}{l}\text { Susu kental manis putih } \\
\text { Sumber Protein Nabati }\end{array}$ & 4 & 26.67 & 4 & 26.67 & 3 & 20.00 & 4 & 26.67 & 0 & 0.00 \\
\hline Tempe & 10 & 66.67 & 2 & 13.33 & 3 & 20.00 & 0 & 0.00 & 0 & 0.00 \\
\hline Tahu & 5 & 33.33 & 8 & 53.33 & 7 & 46.67 & 0 & 0.00 & 0 & 0.00 \\
\hline $\begin{array}{l}\text { Kacang hijau } \\
\text { Sumber Vitamin dan Mineral }\end{array}$ & 5 & 33.33 & 8 & 53.33 & 7 & 46.67 & 0 & 0.00 & 0 & 0.00 \\
\hline Sayur Asem & 4 & 26.67 & 3 & 20.00 & 5 & 33.33 & 3 & 20.00 & 0 & 0.00 \\
\hline Sayur lodeh & 3 & 20.00 & 4 & 26.67 & 6 & 40.00 & 2 & 13.33 & 0 & 0.00 \\
\hline Sawi & 0 & 0.00 & 3 & 20.00 & 10 & 66.67 & 2 & 13.33 & 0 & 0.00 \\
\hline Wortel & 0 & 0.00 & 0 & 0.00 & 9 & 60.00 & 6 & 40.00 & 0 & 0.00 \\
\hline Kangkung & 2 & 13.33 & 8 & 53.33 & 4 & 26.67 & 1 & 6.67 & 0 & 0.00 \\
\hline Bayam & 0 & 0.00 & 7 & 46.67 & 2 & 13.33 & 6 & 40.00 & 0 & 0.00 \\
\hline Sayur Sop & 0 & 0.00 & 1 & 6.67 & 2 & 13.33 & 12 & 80.00 & 0 & 0.00 \\
\hline Jeruk & 3 & 20.00 & 0 & 0.00 & 12 & 80.00 & 0 & 0.00 & 0 & 0.00 \\
\hline Pisang & 10 & 66.67 & 0 & 0.00 & 4 & 26.67 & 0 & 0.00 & 0 & 0.00 \\
\hline Pepaya & 5 & 33.33 & 2 & 13.33 & 8 & 53.33 & 0 & 0.00 & 0 & 0.00 \\
\hline \multicolumn{11}{|l|}{ Lain-lain } \\
\hline Agar-agar & 10 & 66.67 & 2 & 13.33 & 3 & 20.00 & 0 & 0.00 & 0 & 0.00 \\
\hline Ciki & 5 & 33.33 & 8 & 53.33 & 7 & 46.67 & 0 & 0.00 & 0 & 0.00 \\
\hline
\end{tabular}

$66.67 \%$ balita, menyusul tahu (33.33\%), dan kacang hijau (33.33\%). Sebagai sumber vitamin dan mineral, sayur asem, sayur lodeh, kangkung, bayam, jeruk, pisang, dan pepaya merupakan jenis pangan yang relatif sering dikonsumsi oleh balita.

\section{Rancangan Menu Makanan Harian Selama Satu Minggu}

Menurut FAO/WHO (1998) makanan sehat adalah makanan yang aman dikonsumsi dan menyediakan semua zat-zat makanan yang dibutuhkan oleh tubuh untuk hidup sehat. Oleh karena itu, dalam susunan (menu) makanan yang dikonsumsi sehari-hari harus mengandung zat-zat penting tersebut agar kebutuhan tubuh akan zat gizi dapat terpenuhi. Kekurangan maupun kelebihan konsumsi pangan dalam jangka waktu lama akan berdampak buruk bagi kesehatan (Muhilal et al., 1998). Oleh karena itu, disamping memperhatikan biaya konsumsi pangan, dalam penyusunan menu makanan harus memperhatikan juga kontribusi kandungan zat gizi yang dihasilkan sehingga jumlah zat gizi yang dikonsumsi sesuai dengan yang dibutuhkan serta batas bawah dan batas atas dari berat pangan yang dikonsumsi.

Batas bawah konsumsi pangan (kuantil 1) artinya balita sudah terbiasa mengonsumsi pangan kuantitasnya lebih dari nilai batas bawah yang diperoleh, sedangkan batas atas (kuantil 3) artinya bahwa balita terbiasa mengonsumsi pangan dengan kuantitas kurang dari nilai batas atas yang diperoleh (Tabel 4).

Berdasarkan hal tersebut, dirancang contoh menu makanan sehari dengan model yang terdiri atas pangan pokok, pangan nabati, pangan hewani, sayur, buah, dan tambahan lain (selingan) yang ditujukan untuk balita. Menu dirancang berdasarkan AKG, kemampuan daya beli keluarga, dan kebiasaan makan. Berikut ditampilkan contoh rancangan menu makanan sehari untuk balita (Tabel 5). 
Tabel 4. Batas Bawah dan Batas Atas J enis-jenis Pangan Terpilih untuk Rancangan Menu Makanan

\begin{tabular}{|c|c|c|c|c|c|c|c|c|c|c|}
\hline \multirow[t]{2}{*}{ Gol } & \multirow[t]{2}{*}{ Jenis Pangan } & \multicolumn{2}{|c|}{$\begin{array}{c}\text { Berat (per } 100 \\
\text { g/hari) }\end{array}$} & \multicolumn{6}{|c|}{ Rasio kandungan zat gizi pangan terhadap AKG (model) } & \multirow[t]{2}{*}{ Biaya *) } \\
\hline & & Q1 & Q3 & Energi & Protein & Kalsium & Besi & Vit.A & Vit.C & \\
\hline 1 & beras & 1.500 & 2.500 & 0.232 & 0.174 & 0.012 & 0.089 & 0.000 & 0.000 & 0.003 \\
\hline 1 & mie & 0.350 & 0.700 & 0.217 & 0.203 & 0.098 & 0.311 & 0.000 & 0.000 & 0.007 \\
\hline 1 & Roti & 0.200 & 0.500 & 0.161 & 0.203 & 0.040 & 0.278 & 0.000 & 0.000 & 0.306 \\
\hline 1 & Kentang & 0.500 & 1.500 & 0.046 & 0.044 & 0.019 & 0.066 & 0.000 & 0.321 & 0.071 \\
\hline 1 & ubi jalar & 0.750 & 1.500 & 0.068 & 0.040 & 0.052 & 0.067 & 0.015 & 0.420 & 0.050 \\
\hline 2 & tahu & 0.250 & 0.750 & 0.044 & 0.200 & 0.248 & 0.000 & 0.000 & 0.000 & 0.100 \\
\hline 2 & tempe & 0.250 & 0.750 & 0.096 & 0.469 & 0.258 & 1.111 & 0.013 & 0.000 & 0.152 \\
\hline 2 & Kacang hijau & 0.500 & 1.000 & 0.223 & 0.569 & 0.250 & 0.744 & 0.044 & 0.133 & 0.163 \\
\hline 3 & telur ayam & 0.300 & 1.200 & 0.094 & 0.295 & 0.097 & 0.270 & 0.618 & 0.000 & 0.185 \\
\hline 3 & ikan segar.. & 0.250 & 0.500 & 0.058 & 0.349 & 0.032 & 0.089 & 0.084 & 0.000 & 0.233 \\
\hline 3 & kental manis putih & 0.420 & 1.000 & 0.217 & 0.210 & 0.550 & 0.022 & 0.389 & 0.022 & 0.391 \\
\hline 3 & Daging Ayam & 0.500 & 2.000 & 0.113 & 0.271 & 0.016 & 0.097 & 0.358 & 0.000 & 0.350 \\
\hline 3 & ikan $\operatorname{asin} . . . . .$. & 0.125 & 0.250 & 0.087 & 0.754 & 0.280 & 0.194 & 0.000 & 0.000 & 0.225 \\
\hline 3 & Teri & 0.083 & 0.150 & 0.110 & 0.856 & 2.400 & 0.400 & 0.144 & 0.000 & 0.200 \\
\hline 3 & Rebon & 0.083 & 0.150 & 0.193 & 0.754 & 4.612 & 2.378 & 0.000 & 0.000 & 0.158 \\
\hline 3 & Ikan bandeng & 0.250 & 0.500 & 0.067 & 0.410 & 0.032 & 0.178 & 0.084 & 0.000 & 0.217 \\
\hline 3 & Ikan kembung & 0.250 & 0.500 & 0.053 & 0.451 & 0.032 & 0.089 & 0.016 & 0.000 & 0.233 \\
\hline 3 & Cumi-cumi & 0.250 & 0.500 & 0.048 & 0.413 & 0.064 & 0.200 & 0.000 & 0.000 & 0.250 \\
\hline 3 & Udang & 0.250 & 0.500 & 0.171 & 1.440 & 2.176 & 0.630 & 0.130 & 0.000 & 0.167 \\
\hline 4 & Tomat & 0.463 & 1.250 & 0.012 & 0.024 & 0.010 & 0.053 & 0.475 & 0.844 & 0.050 \\
\hline 4 & kangkung & 0.250 & 0.750 & 0.013 & 0.054 & 0.102 & 0.194 & 1.470 & 0.498 & 0.111 \\
\hline 4 & sayur asem & 0.500 & 1.000 & 0.031 & 0.063 & 0.051 & 0.063 & 0.096 & 0.388 & 0.122 \\
\hline 4 & Sayur Sop & 0.500 & 1.000 & 0.010 & 0.015 & 0.025 & 0.056 & 0.356 & 0.324 & 0.167 \\
\hline 4 & Kol / Kubis & 0.250 & 0.500 & 0.012 & 0.027 & 0.069 & 0.042 & 0.017 & 0.833 & 0.033 \\
\hline 4 & sawi & 0.200 & 0.600 & 0.012 & 0.051 & 0.383 & 0.280 & 1.873 & 1.972 & 0.050 \\
\hline 4 & Bayam & 0.250 & 1.000 & 0.016 & 0.064 & 0.379 & 0.308 & 1.442 & 1.262 & 0.097 \\
\hline 4 & wortel & 0.200 & 0.600 & 0.024 & 0.027 & 0.069 & 0.078 & 3.520 & 0.117 & 0.042 \\
\hline 4 & Buncis & 0.250 & 0.500 & 0.020 & 0.055 & 0.012 & 0.110 & 0.190 & 0.380 & 0.100 \\
\hline 4 & kcng pnjang & 0.150 & 0.500 & 0.021 & 0.052 & 0.074 & 0.058 & 0.083 & 0.350 & 0.092 \\
\hline 4 & Ketimun & 0.450 & 1.000 & 0.005 & 0.013 & 0.014 & 0.023 & 0.000 & 0.124 & 0.061 \\
\hline 5 & Pisang lampung & 0.200 & 0.600 & 0.048 & 0.025 & 0.015 & 0.075 & 0.150 & 0.067 & 0.063 \\
\hline 5 & Pisang ambon & 0.375 & 1.000 & 0.048 & 0.023 & 0.012 & 0.042 & 0.035 & 0.050 & 0.069 \\
\hline 5 & pepaya & 0.500 & 1.000 & 0.022 & 0.010 & 0.035 & 0.142 & 0.093 & 1.300 & 0.100 \\
\hline 5 & jeruk & 0.300 & 1.000 & 0.021 & 0.017 & 0.048 & 0.032 & 0.046 & 0.784 & 0.133 \\
\hline 6 & minyak kelapa & 0.200 & 0.500 & 0.561 & 0.026 & 0.000 & 0.000 & 0.000 & 0.000 & 0.167 \\
\hline 6 & Gula pasir & 0.200 & 0.400 & 0.235 & 0.000 & 0.010 & 0.011 & 0.000 & 0.000 & 0.113 \\
\hline 6 & Agar-agar & 0.450 & 0.950 & 0.000 & 0.000 & 0.800 & 0.556 & 0.000 & 0.000 & 0.450 \\
\hline
\end{tabular}

Keterangan: Q1 = kuantil 1 sebagai batas bawah, Q3 = kuantil 3 sebagai batas atas

*) Biaya dalam model goal programming berupa perbandingan antara harga terhadap biaya (alokasi pengeluaran pangan anak balita) dari masing-masing pangan terpilih.

Tabel 5. Contoh Rancangan Menu Makanan Satu Hari untuk Anak Balita

\begin{tabular}{|c|c|c|c|c|c|c|c|c|c|c|}
\hline \multirow[b]{2}{*}{ Menu } & \multirow[b]{2}{*}{ Jenis pangan } & \multicolumn{2}{|c|}{ Jumlah pangan } & \multirow{2}{*}{$\frac{\text { Biaya }}{\text { (Rp) }}$} & \multicolumn{6}{|c|}{ Kandungan zat gizi menu makanan } \\
\hline & & URT & gram & & $\begin{array}{c}\text { Energi } \\
\text { (Kal) }\end{array}$ & $\begin{array}{c}\text { Protein } \\
\text { (g) }\end{array}$ & $\mathrm{Ca}(\mathrm{mg})$ & $\begin{array}{l}\text { Besi } \\
(\mathrm{mg})\end{array}$ & $\begin{array}{l}\text { Vit.A } \\
\text { (RE) }\end{array}$ & $\begin{array}{l}\text { Vit.C } \\
\text { (mg) }\end{array}$ \\
\hline \multirow{14}{*}{ 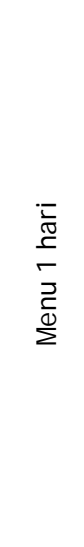 } & Beras & $1.5 \mathrm{gls}$ & 150 & 600 & 540 & 10.2 & 9.0 & 1.2 & 0.0 & 0 \\
\hline & biskuit & 6 buah & 37 & 370 & 163 & 4.0 & 206.7 & 0.0 & 0.0 & 1 \\
\hline & Telur ayam & $2 \mathrm{btr}$ & 89 & 999 & 146 & 11.5 & 48.6 & 2.4 & 278.1 & 0 \\
\hline & Susu kental manis & $3 \mathrm{sdm}$ & 31 & 253 & 101 & 2.5 & 82.5 & 0.1 & 52.5 & 0 \\
\hline & Tempe & 2 ptng & 53 & 405 & 75 & 9 & 85 & 5 & 3 & 0 \\
\hline & Tahu & 2 buah & 50 & 300 & 34 & 3.9 & 62.0 & 0.0 & 0.0 & 0 \\
\hline & Sawi putih & $1 / 4 \mathrm{gls}$ & 22 & 57 & 4 & 0 & 42 & 1 & 184 & 19 \\
\hline & Pepaya & $1 \mathrm{ptg}$ & 36 & 216 & 17 & 1 & 8 & 1 & 20 & 28 \\
\hline & Pisang ambon & 1 buah & 52 & 208 & 50 & 0.3 & 4.0 & 0.9 & 10.5 & 2 \\
\hline & Minyak kelapa & $4 \mathrm{sdm}$ & 40 & 320 & 348 & 0.6 & 0.0 & 0.3 & 0.0 & 0 \\
\hline & Gula & $1 \mathrm{sdm}$ & 10 & 72 & 36.4 & 0 & 0.5 & 0 & 0 & 0 \\
\hline & agar-agar & $1 \mathrm{ptg}$ & 20 & 230 & 0 & 0 & 80 & 0 & 0 & 0 \\
\hline & & Total & & 4030 & 1513 & 43.1 & 627.9 & 11.6 & 548.4 & 50 \\
\hline & \multicolumn{3}{|c|}{ Rasio kandungan gizi (\%) } & & 98 & 110 & 126 & 129 & 122 & 111 \\
\hline
\end{tabular}


Kontribusi kandungan zat gizi dalam contoh rancangan menu makanan pada Tabel 5sudah dibuat sedemikian rupa sehingga dihasilkan rasio yang sesuai dengan AKG balita. Kontribusi kandungan energi, protein, kalsium zat besi, vitamin A dan vitamin C pada rancangan menu diatas sudah tergolong kategori normal. Rasio yang dihasilkan sudah sesuai dengan cut off point normal menurut Depkes (1996), yaitu antara $90-119 \%$ untuk energi dan protein, sedangkan untuk vitamin dan mineral digunakan batasan normal Gibson (2005) yaitu di atas $77 \%$

Secara umum, kontribusi zat gizi yang diperoleh dari menu makanan yang telah dirancang tergolong dalam kategori baik. Kontribusi vitamin dan mineral dari rancangan menu makanan menggunakan batasan maksimum yang diperbolehkan (tolerable upper intake level, UL) sehingga batas atas kontribusi vitamin dan mineral dirancang jauh di bawah batas toksisitas. Bila dilihat dari biaya, maka yang harus dikeluarkan untuk menu tersebut adalah Rp 4 030, jumlah yang lebih kecil dibanding pengeluaran pangan per kapita balita yaitu Rp 4194.

\section{KESIMPULAN}

Keluarga contoh merupakan keluarga miskin dengan rataan pengeluaran per kapita per hari sebesar Rp 25134 . Pengeluaran pangan per kapita per hari $68.10 \%$ dari pengeluaran total atau sebesar Rp 17 116. Sedangkan rataan pengeluaran pangan per kapita per hari untuk balita sebesar Rp 4194.

Terdapat 23 jenis pangan sebagai kombinasi pangan selama 1 minggu, terdiri atas 5 jenis pangan sumber karbohidrat, 4 jenis pangan sumber protein hewani, 3 jenis pangan (tempe, tahu, dan kacang hijau) sumber protein nabati, dan 10 jenis pangan sumber vitamin dan mineral.

Batas bawah adalah kuartil 1 (Q1) dan batas atas adalah kuartil3 (Q3). Solusi model goal programming menghasilkan sasaran di dalam batas yang diperbolehkan, yaitu Energi dan protein antara $90-110 \%$ dan untuk vitamin dan mineral $>77 \%$, dengan biaya sesuai daya beli yaitu Rp 4030 .

\section{DAFTAR PUSTAKA}

Akmal S. 2003. Optimasi Pemenuhan Kecukupan Gizi berdasarkan Ketersediaan Pangan Sebelum dan Semasa Krisis Ekonomi di Propinsi Lampung. Tesis Magister Sekolah Pascasarjana, IPB, Bogor.

FAO/WHO. 1998. Preparation and Use of FoodBase Dietary Guidelines. WHO, Geneva.

Gibson RS. 2005. Principles of Nutritional Assesment Ed ke-2. Oxford University Press, London.

Hardinsyah. 2001. Pembangunan Pangan di Era Ekonomi Daerah Prosiding Dialog dan Lokakarya Kebijakan dan Program Pangan, Ketahanan Pangan di Era Ekonomi. Pusat Studi Kebijakan Pangan dan Gizi IPB, Bogor.

Muhilal, Jalal F \& Hardinsyah. 1998. Angka Kecukupan Gizi yang Dianjurkan. Dalam Winarno dkk. (Eds.), Pangan dan Gizi Masa Depan: Meningkatkan Produktivitas dan Daya Saing Bangsa. Prosiding Widyakarya Pangan dan Gizi Nasional VI (hlm. 843-844), 17-20 Februari. LIPI, J akarta.

Siswanto. 1991. Goal Programming dengan Menggunakan Lindo. PT Elex Media Komputindo, J akarta.

Soekirman. 2000. IImu Gizi dan Aplikasinya untuk Keluarga dan Masyarakat. Direktorat Jenderal Pendidikan dan Penelitian, Departemen Pendidikan Indonesia, J akarta.

Tanziha I. 2005. Analisis Peubah Konsumsi dan Sosial Ekonomi untuk menentukan Determinan dan Indikator Kelaparan. Disertasi Doktoral Sekolah Pascasarjana, IPB, Bogor.

Tanziha I. 2008. Penguatan Modal Sosial untuk Pencegahan dan Penanggulangan Kelaparan. Departemen Gizi Masyarakat, Fakultas Ekologi Manusia, IPB, Bogor.

[WNPG] Widyakarya Nasional Pangan \& Gizi. 2004. Ketahanan Pangan dan Gizi di Era Otonomi Daerah dan Globalisasi. Prosiding Widyakarya Nasional Pangan dan Gizi VIII.17-19 Mei. LIPI, J akarta. 